\title{
A Musical Analysis of Mythical Thought in the Work of Claude Lévi-Strauss
}

\author{
David Kozel
}

\section{Introduction}

The systematic set of ideas concerning the forms of relationships between the myths of primitive societies and music which can be found in the work of Claude Lévi-Strauss (1908-2009) is an essential and well-known part of the legacy he left behind through his influence on scientific discourse and the diversification of the humanities over the course of the second half of the $20^{\text {th }}$ century. A number of authors have apparently had and continue to have issues with the integral acceptance of the "musical" component of Strauss's structural anthropology, irrespective of their competence to judge this aspect without any links to their association with the anthropological or musicological communities. As a result, although the musical analogy appears to be an aesthetically uplifting and tempting method for the serious study of mythology in non-European cultures, it also seems to be somewhat inappropriate and superfluous. The application of the principles of archaic mythical thought to contemporary music and categories of musical works with connotations of European culture may indeed be viewed as an amusing commentary with a hermeneutic after-taste, as they are not part of the process of exploring the phenomenon of music which has a clearly and academically defined tradition and, at most, take on the semblance of a colourful decoration. With the unavoidable passage of time and in spite of the frequently justified concerns of generalisation and vagueness, it is possible to note overlaps from both sides. These are the forced result of not only the methodological links between the structural analysis of mythology and music, but also due to a terminological affinity.

In the case of Lévi-Strauss, the analytical use of music as a tool for exploring mythology is obviously rooted in his interest in European art music and its structural characteristics. One might eve argue that he was greatly (eruditely) fascinated by this music genre even beyond the scope of this anthropological focus. At the end of The Naked Man, Lévi-Strauss even reveals the personal level of his motivation, when he states that his written tetralogy was an attempt to compensate for his inability to compose by creating the 
"negative" of a symphony, which some future composer will hopefully be able to convert into its "positive" musical equivalent: "[...] I have tried to construct with meanings a composition comparable to those that music creates with sounds [...]." ${ }^{142}$ The inclusion of music in anthropological methodology is not, however, random or superficial; it indicates the deeper roots of the author's theses within the comprehensive whole of anthropological theories (structuralism), even with the risk that these beliefs may be questioned. The ontological links between mythology and music are pointed out by, for example, Eric Prieto: "Music interests Lévi-Strauss as a model for myth not only because he sees in it a clear justification for the ontological premises of structuralism as a whole [...]." ${ }^{143}$

References to music are interwoven within the majority of Lévi-Strauss's most important written works, which provides another indication of his continuous contemplation of the "musicalisation of mythology". Mention should first be made of his initial study - The Structural Study of Myth (1955) - which includes an analysis of the Oedipus myth, using the reading of this myth as an orchestral score with a linguistic approach. A partial, unfinished version of Lévi-Strauss's theory is also included in his Anthropologie structurale from 1958 (hereinafter referred to by its English title: Structural Anthropology). The most extensive methodological links in relation to music may be found in his tetralogy Mythologiques I-IV from the 1960s and early 1970s, which is focused specifically on North and South American mythology and consists of the following volumes: Le Cru et le cuit (1964, The Raw and the Cooked), Du miel aux cendres (1966, From Honey to Ashes), L'Origine des manières de table (1968, The Origin of Table Manners), and L'Homme nu (1971, The Naked Man). In the introductory Overture chapter of The Raw and the Cooked, Lévi-Strauss's focus on music is made clear by his reference to Wagner's tetralogy. The remaining chapters, also named according to musical forms from European art music, are yet another way in which the musical structure of his work is reflected in relation to his selected "key" myth from the Bororo tribe from central Brazil and its transformational relationship to other myths, both far and near. In the next two volumes of his Mythologiques tetralogy, Lévi-Strauss's musical approach is immediately present only in the way the text and the myths themselves are structured and conceived. However, it once again resounds in its full glory, with some revisions to his initial ideas, in the closing Finale chapter of The Naked Man. Lévi-Strauss perceives his Mythologiques cycle as a myth about mythology; it presents a code to understanding mythology that is not external to the myths, but is structurally related to them. His work imitates the movement of mythical thought through references to the past and to what is different. When creating this meta-language for analysing myths, the essential basis is the concept of language as the primary code, myth as the secondary code, while the book itself represents the third level which ensures the

142 Claude Lévi-Strauss, The Naked Man, Mythologiques vol. 4 (Chicago: University of Chicago Press, 1990), 649.

143 Eric Prieto, Listening In. Music, Mind and the Modernist Narrative (Lincoln: University of Nebraska Press, 2002), 262. 
mutual transferability of the myths amongst themselves. ${ }^{144}$ Another relevant work is the chapter Myth and Music from the publication entitled Myth and Meaning (1978, a cycle of broadcast lectures), in which Lévi-Strauss summarises his basic ideas (particularly the Finale chapter) and supplements them with, amongst other things, an interpretation of Richard Wagner's mythological motifs. ${ }^{145}$

This study focuses on selected topics from the investigated relationships between mythology and music, with a specific emphasis placed on methodologically classifying them into thematic areas according to their characteristics, even though the individual categories are not mutually permeable. The specified process can be perceived as the interpretation of text with a clearly defined musicological foundation, as well as an effort to summarise and draw attention to simulative moments in mythical thought concerning music and musical thought sui generis. To start with, it can be stated that these thematic areas form different levels associated with the individual structural homologies of mythology and music, the methodological tools used to analyse myths with the help of music, the principles governing the styles and forms in the development of European art music and composed poetry. The fact that some of Lévi-Strauss's theories are questioned occurs specifically because there is no differentiation between the various levels that have been outlined. The purpose of this study is not to create any new schema or rigid classification system, but rather to define frameworks for the individual areas, which I am convinced represent a more useful and purposeful environment for their interpretation and their further inclusion in the theoretical and historical directions of musicology, making it possible to take into account other disciplines (philosophy, religious studies, sociology and others). ${ }^{146}$

144 Claude Lévi-Strauss, The Raw and the Cooked, Mythologiques, vol. 1 (Chicago: University of Chicago Press, 1983), 12.

145 Claude Lévi-Strauss, "Myth and Music," in Myth and Meaning (Toronto: University of Toronto Press, 1978), 44-54. Other works are cited further in the text. The study also refers to the following works: Tristes Tropiques (1955, The Sad Tropics, with references to Igor Stravinsky's Les noces); Regarder, écouter, lire (1993, Look, Listen, Read, references to Jean-Philippe Rameau's theory of musical harmony); The View From Afar (1992, reflections on Richard Wagner's Der Ring des Nibelungen); and others.

146 Jean Jacques Nattiez points out the one-sided perspective of philosophers and musicologists with regard to Lévi-Strauss's musical motifs: "But philosophers and musicians have often discussed Lévi-Strauss's proposals in terms of their own disciplines, without really examining the underlying motivations that drive his anthropology into the arms of music." Jean Jacques Nattiez, The Battle of Chronos and Orpheus (Oxford: Oxford University Press, 2004), 57. 


\section{Structuralist Perspective of Myth and Music}

Lévi-Strauss's analysis of myth is based on empirical categories (e.g., the raw and the cooked, the fresh and the decayed, the male and the female, up and down, etc.), aimed at abstract concepts and linking them into propositions. Within these categories, it is possible to overcome internally inherent contradictions when they are broken down to the level of symbols. As a result of its rational organisation of sensory experience, music (particularly instrumental music with the absence of voice, which is linked to language in spite of its musical nature) is, as compared to painting, ${ }^{147}$ closer to myth, as it lies between logical thinking and aesthetic perception. This uncovers the logic hidden within the sensory qualities of myth and musical works in relation not only to abstract concepts of existence, but also to emotionality: "[...] a musical work is a sound system capable of inducing meanings in the mind of the listener." ${ }^{148}$ The analysis of myth through the use of music is carried out at the level of the methodological system. It takes place the most often, however, at the metaphoric, homologous, or isometric level. Musical structures are also applicable because, according to Lévi-Strauss, music is able to overcome the aforementioned binary oppositions, which form the basic principle of mythical thought and language - the essence of human thought as it exists in their unconscious structures. ${ }^{149}$ Myth and music are instruments that overcome these oppositions by making up for the lack of logic. In his work, Lévi-Strauss demonstrates the basic principles of how myth and music are structured. This includes, for example, transformation, repetition, recurrence, imitation and transposition. Although the meaning of these concepts is primarily perceived as logico-mathematical, their proximity to musical terminology and thematic work with musical thought is apparent.

In the case of Lévi-Strauss, the musical analysis of myth is, in addition to sociological and ethnological theories, based on the concepts of structural linguistics defined by Ferdinand de Saussure, the linguistics of Roman Jakobson, and the philosophy of Immanuel Kant and George Wilhelm Friedrich Hegel, as they are applied to other cultural spheres. Myth and music are viewed from the perspective of language in order to highlight their specificity. Although the methodological inclusion of music in Mythologiques is independent of other aspects, its relationship to language is always taken into account. ${ }^{150} \mathrm{In}$ order to understand mythology, it must always be viewed from the perspective of both music as well as language.

Lévi-Strauss defines four fields of structural studies: mathematical demonstration, natural languages, musical works and myths. Whilst mathematical models, as the direct

${ }_{147}$ Compare Claude Lévi-Strauss, The Raw and the Cooked, 18-22.

148 Claude Lévi-Strauss, The Naked Man, 651.

149 Compare Ino Rossi, "The Unconscious in the Anthropology of Claude Lévi-Strauss," American Anthropologist, New Series 75, No. 1 (1973): 20-48.

150 Compare Robert Launay, "Myth and Music: the Musical Epigraphs to the Raw and the Cooked," in Histories of Anthropology Annual, Vol. 7 (Nebraska: University of Nebraska Press, 2011), 83-90. 
opposite of language, are abstract, language constitutes meaning and sound (the phonetic aspects). Myths are primarily founded on meaning and the phonetic aspects are less significant because myth, as compared to poetry, is transformable within its own system, i.e., it is structurally translatable without any significant impact on its significance. Lévi-Strauss argues that music is based on sound but separated from meaning, and, therefore, we have a natural tendency to provide it with meaning. Music is infinitely translatable only to other music within its own closed system; it is unmediated and has a unique, purely musical, structure. ${ }^{151}$ Lévi-Strauss goes on to describe the process of the creation of myth and music. Over the course of development, although music became separate from language it retained its formal structure; it takes sound from speech. Myth separated from language to the benefit of meaning. ${ }^{152}$ Looking at it from a different perspective, Lévi-Strauss provides evidence of the insurmountable differences in the relationship structure of language myth - music. Whilst in the case of language, its constitutive elements are phonemes, which are combined in different ways to create different meanings, in music the basic element is a tone. An isolated tone lacks meaning (although this statement is subject to dispute), but, when combined with other tones, it creates music, allowing us to speak of "tonemes". Both language and music may subsequently be compared from the perspective of structure. In the case of language, phonemes are joined together to create words from which sentences are made. As far as music is concerned, the level of words is missing, as it is the individual tones that are combined to form a musical sentence using a melodic phrase. In myth, there are no constitutive phonemes and the basic element is the word (which is absent in the case of music); however, in myth, as compared to music, there is no equivalent of a phoneme. In other words, in all cases there is one level missing. ${ }^{153}$

The process of myth analysis always remains unfinished (Lévi-Strauss argues that it is never-ending) due to the continuous breaking down of motifs. "Divergence of sequences and themes is a fundamental characteristic of mythological thought [...]." ${ }^{154}$ This processuality may also be seen elsewhere within the context of interpreting musical and mythical communication. The actual composition process may itself be considered mythical, since, as in the case of myth, it is founded on consistent confrontation, references, and the transformation of other musical structures - either the composer's own or those taken from past and present music. According to our author, the composer must carry out this confrontation in order to create an originally structured theme. ${ }^{155}$ The relationship between the mythical communication process and music is also present in the process of negating past tradition as a stimulus to create new forms of musical expression.

\footnotetext{
151 The idea of the non-transformability of musical and mythical expression may also be found in the work of Carl Kerényi. Carl Kerényi, "Prolegomena," in Carl Gustav Jung and Carl Kerényi, The Science of Mythology (London: Routledge, 2002), 5.

152 Claude Lévi-Strauss, The Naked Man, 647-648.

153 Claude Lévi-Strauss, "Myth and Music," 51-52.

154 Claude Lévi-Strauss, The Raw and the Cooked, 5.

155 Claude Lévi-Strauss, The Naked Man, 646.
} 
Lévi-Strauss draws attention to the anonymity of myth and places it within the context of music: "Myths are anonymous: from the moment they are seen as myths, and whatever their real origins, they exist only as elements embodied in a tradition." ${ }^{156}$ At the time a myth is told, the communication of this myth comes as if out of nowhere, supporting its supernatural origin. This anonymity is compared to our lack of knowledge about the spiritual conditions involved in musical creation. Music specifically combines that which is understandable but, at the same time, untranslatable. As is aptly noted, the majority of people are able to understand music, however, only a very few are able to produce it. As a result, composers are compared to gods: "[...] the musical creator is a being comparable to the gods, and music itself the supreme mystery of the science of man, a mystery that all the various disciplines come up against and which holds the key to their progress." ${ }^{157}$ The emphasis traditionally placed by structuralists on the role of the creator as compared to the role of recipient is, however, a relatively equivalent assessment of the relationship between composer and listener. Listeners have space open to receive music; they are the creators of the "negative" image of the composer's creation. The co-participation that exists between a music composer and a music listener takes place at the intellectual and sensory levels. ${ }^{158}$ In the case of myth and music, there is even a reversal in the roles of broadcaster and recipient. "Thus the myth and the musical work are like conductors of an orchestra, whose audience becomes the silent performers." ${ }^{159}$ The possible poetic nature of this type of expression is, within the rigorous definition of the word, a justifiable reference to the methodological premises for understanding myth. Lévi-Strauss nevertheless bases his premises on the thesis that myth analysis will not reveal how people think, but rather how the thoughts founded in myth are interconnected, which is one of the basic ideas behind his structural anthropology and myth analysis overall: "I therefore claim to show, not how men think in myths, but how myths operate in men's minds without their being aware of the fact." ${ }^{160}$ From the structuralist perspective, myths consist of a set of (more or less fixed) relationships between constitutively significant units (the mythical events, their functions) and the various ways in which they are combined, which makes it possible to reveal their structural principles and define their semantic function.

\section{Reading Myths as Musical Scores}

Lévi-Strauss's structural analysis of the Oedipus myth firstly exemplifies the methodological output of "reading" a myth for the purpose of revealing its internal structure, which, at the unconscious level, draws attention to the bridge between the relevant oppositions

156 Claude Lévi-Strauss, The Raw and the Cooked, 18.

157 Ibid.

158 Claude Lévi-Strauss, The Naked Man, 654-655.

159 Claude Lévi-Strauss, The Raw and the Cooked, 17.

160 Ibid., 12. 
present in mythical thinking. In other words, it is an analysis of the langue of the myth, which conceals itself behind what the myth says - its parole. This indicates the structural nature of myth and language and the way in which they are related. The constitutive units of myths are "mythemes", which, as compared to the phonemes and morphemes of the spoken language, are situated at a higher level in the structure. Related mythemes cluster together and create functional units of meaning at various levels, which are revealed through the structural analysis of myths. This is where Lévi-Strauss's comparison of the analytical reading of a myth with the reading of a musical score comes into play: reading not only the melody (the horizontal line), from left to right, sheet by sheet, individual motif by individual motif, but, at the same time, also reading vertically from top to bottom in order to disclose the harmonic unity of the internal significance of the myth/music. ${ }^{161}$ What differentiates the two is the method used to tell the myth and how it is understood:

Were we to tell the myth, we would disregard the columns and read the rows from left to right and from top to bottom. But if we want to understand the myth, then we will have to disregard one half of the diachronic dimension (top to bottom) and read from left to right, column after column, each one being considered as a unit. ${ }^{162}$

The mythemes are subsequently numbered sequentially, and arranged into columns according to the shared function. The lines of this "score" point out the development of individual mythemes over time. Ultimately, the internal structure of the Oedipus myth comes to light by reading the columns from left to right, connecting the diachronic dimension with the synchronic, the syntagmatic with the paradigmatic. According to Lévi-Strauss, this "musical" reading makes it possible to discover the significance thanks to the similarity between myth and music. ${ }^{163}$ This analogy also draws attention to additional conformities and the thought-inspiring nature of the approach. During our own diachronic reading (hearing) of a myth, we are able to note only the individual events and motifs as they follow one another in what can be termed as in unison. Conversely, musical compositions may contain noticeable overlaps of multiple motifs simultaneously within the individual voices (or layers) within one short period of time. The synchronous analysis of myth draws attention to the processes of perceiving music through memory reconstruction in relation to structure - the individual musical thoughts are retained in one's memory when listening to a composition in order to allow the listener to sense their interrelationships and the existing successions after the composition has ended with the aim of creating a musical image of the entirety of the piece. ${ }^{164}$ This process is cognitively

161 For more information, refer to: Claude Lévi-Strauss, Structural Anthropology (New York: Anchor, 1963), 213-217.

162 Ibid., 214.

163 Claude Lévi-Strauss, "Myth and Music," 44-45.

164 Compare with the following citation: "Thus there is a kind of continuous reconstruction taking place in the mind of the listener to music or the listener to a mythical story." Ibid., 49. 
very demanding, however, and certain compositional relationships may be revealed only after returning to the musical material with, for example, the sheet music, or by creating a written outline. In the case of Lévi-Strauss, the use of the orchestral approach to myth is primarily determined (as has already been mentioned) on the basis of the methodological and practical requirements resulting from the synchronous level of the myth and the emphasis placed on it.

\section{The Musical Form of Myth and the Transformation of Musical Styles}

By integrating musical forms into the myth analysis presented in The Raw and the Cooked, Lévi-Strauss attempts not only to justify the appropriateness of the selected method due to the inability to adequately separate the mythological material using traditional ethnological methods, but also to draw attention to the more important interconnections between musical and myth structures. The individual chapters are entitled according to musical forms (or, more precisely, forms and types) in poetic connection with specific myths, and, with the exception of the initial Overture, the entire work is one whole comprising five parts. ${ }^{165}$ According to the author, the selected approach made it possible to capture the movement and nature of the mythical material with its linear and diffuse rhythm, the slowing down and the acceleration, the alternating solo and tutti sections. ${ }^{166}$ The musical forms in their contemporary European form provide models that may be used to analyse myths and make it possible to discover their structure, which has thus far remained hidden from us. The structural similarity of myth and music, based on the universality of the subconscious processes of the human mind, although modified and mediated by culture, has historically already been analysed with the use of music. This universality does not directly apply to specific musical or mythical forms, but rather to the principles of thought that are structured through the use of binary oppositions and are subsequently overcome through specific mythical or musical methods. This process, as outlined, is chronologically reversible: mythical forms found a means of expression in music which took over the structures of mythical thought; anthropology may apply this in reverse when studying myths. Within the structures of the investigated myths, Lévi-Strauss finds a variety of musical forms (from variations to sonatas), but, in his opinion, the most important appear to be the fugue and various polyphonic forms. From the perspective of mythological significance, the key principle is the imitation of motifs by following through and escalation.

165 List of the chapter titles: I Theme and Variations (Bororo Song, Ge Variations), II The "Good Manners" Sonata, A Short Symphony, III Fugue of the Five Senses, The Opossum's Cantata, IV Well-Tempered Astronomy (Three Part Inventions, Double Inverted Canon, Toccata and Fugue, Chromatic Piece), V Rustic Symphony in Three Movements (Divertissement on a Folk Theme, Bird Chorus, The Wedding).

166 Claude Lévi-Strauss, The Raw and the Cooked, 14. 
Lévi-Strauss views the affinity between myth and music as a relationship resulting from structural similarities associated with the synchronous dimension of myth and musical scores, but also from the perspective of their closeness in time during a specific stage in the development of European (art) culture. According to Lévi-Strauss, during the Renaissance and then gradually during the $17^{\text {th }}$ century and primarily during the $18^{\text {th }}$ and $19^{\text {th }}$ centuries, music became mythical in the sense that, within its structure, it took over forms originally expressed in the myths of antiquity; it became mythical itself by assuming the functions and structures of mythology. The gradual "death of myth" during this period is, in addition to being linked with secularisation, also related to the advent of Cartesian rationalism and the dominance of scientific thought over the mythical sphere. "It is exactly as if music had completely changed its traditional shape in order to take over the function - the intellectual as well as emotive function - which mythical thought was giving up more or less at the same period." ${ }^{167}$ It is specifically in the rise of new musical forms, such as the fugue and the sonata, that Lévi-Strauss sees the causality resulting from the paradigmatic change in musical expression. ${ }^{168} \mathrm{He}$ in no way interferes in the independent development of musical styles or any other art form, but draws attention to the structural changes and principles in both artistic as well as mythical thought. This enables him to link such diverse areas as myth and musical works. The symmetry of myth and music is, however, strictly limited to the European environment and the concept of musical works that is typically associated with it. The representative composers include Girolamo Frescobaldi, Johann Sebastian Bach, Ludwig van Beethoven, and, of course, Richard Wagner as the "originator of the structural analysis of myths". ${ }^{169}$ The above-mentioned musical expression is also complementarily placed into relation with the literary form of novels, which began to replace legends with a mythological core over the same period. Music became mythical, and mythical storytelling was transformed into novels: "In short, it is as if music and literature had shared the heritage of myth between them." 170

Lévi-Strauss makes only slight mention of possible further developments in music after the $19^{\text {th }}$ century (and the associated dominance of the tonal system) in a short passage in his The Naked Man. ${ }^{171}$ If Wagner is to be considered an example of an individual with an unusually strong awareness of the mythical structure of music, Claude Debussy is another composer who brought this process to its peak. A more detailed explanation

167 Claude Lévi-Strauss, "Myth and Music," 46.

168 It should be added that this occurs at the point where dominance transferred from a polyphonic to a homophonic style. Lévi-Strauss does reflect on obvious changes in style over the course of historical development, however, at a more general level, in relation to the overall cultural transformation.

169 Claude Lévi-Strauss, The Raw and the Cooked, 15. For more information, refer to: Claude Lévi-Strauss, "Myth and Music," 46-49. In relation to Wagner, compare also the studies completed by the anthropologist John Leavitt: John Leavitt, "Mytheme and Motif: Lévi-Strauss and Wagner," Intersections: Canadian Journal of Music 30, No. 1 (2010): 95-116.

Claude Lévi-Strauss, The Naked Man, 653.

171 Ibid., 654. Reflections on the development of contemporary music are also briefly covered in Claude Lévi-Strauss, "Myth and Music," 54. 
in the text cannot be found, however, and it may be considered a mere supplement to the musical theme followed in Mythologiques. Lévi-Strauss continues to describe the gradual removal of mythical structures from $20^{\text {th }}$ century music (particularly during the second half) and the process of the realisation of myth as discourse (reflecting the influence of Hegelian thought). He partially reveals a possible relationship with serial music, which, during the period in question, he either considers representative of contemporary music, or at least limits his work to only this composition method, ${ }^{172}$ and avoids the expressive and rhapsodic form of the disappearing novel to the benefit of music in a way that is comparable to the changes at the start of the new era in the case of myth and music. As regards the topic of $20^{\text {th }}$ century music, Lévi-Strauss also refers to musique concrète in the Overture chapter of The Raw and the Cooked, but his assessment is negative in all respects: "Musique concrète may be intoxicated with the illusion that it is saying something; in fact it is floundering in non-significance." " 173 According to Lévi-Strauss, the reasons for this is that sounds, which were originally natural and had clear semantic relationships, once they are modified through musical composition are removed from the causal links to the detriment of musical tomes (which he refers to as "pseudo-tones"), consequently establishing an unclear system of newly articulated relationships. At this point, one of the fundamental principles of structural anthropology may be seen, specifically the differentiation and contradictions between nature and culture. ${ }^{174}$ Lévi-Strauss has a more positive attitude with regard to serial music. In spite of the many differences that exist, he values the fact that it has comparable characteristics with structuralism, i.e., a well-defined structure and syntax, theoretical ambitions, systematic organisation and a lack of trust in mechanistic and empirical solutions. Most important is the fact that tonality is retained in serial music as well as in the organisation of the level of the music as an articulated

172 Lévi-Strauss's theses do not represent an attempt to structurally analyse contemporary music and completely overlook the rich developments in music during the first half of the $20^{\text {th }}$ century. They also do not mention other important musical characteristics of the second half, such as electronic and electro-acoustic music, aleatoric music, minimalism, and others. It may even be possible to view the reasons for this one-sidedness in relation to the questionable part of his theories: he comments only on those directions in music that are either in conflict or in agreement with the paradigms of structural anthropology and the musical analysis of myth.

Claude Lévi-Strauss, The Raw and the Cooked, 23.

174 Josef Fulka focuses on the interpretational elaboration of these premises of Lévi-Strauss within the broader aesthetic context. He confronts Lévi-Strauss's text with Pierre Schaeffer's Traité des objets musicaux, which was published two years after The Raw and the Cooked. The composer manipulates sound objects with the intent of creating new musical significance, specifically without the need for a link to the duality of nature-culture (i.e., natural sound and musical tone). Schaeffer discovers an overlooked dimension of noise, and consequently timbre, in musical sound. Fulka draws attention to Lévi-Strauss's insufficient coverage of the aspect of timbre as one of the most intensively developed aspects of $20^{\text {th }}$ century music within the context of his opposing argument differentiating between sound and tone colour. Josef Fulka, "Lévi-Strauss, Schaeffer, Wagner: hudební struktura mýtu," Teorie védy 30, No. 1 (2009): 127-135. 
language in the linguistic sense of the word (i.e., the organisation of tonal height, timbre, to "total organisation"). ${ }^{175}$

It is possible to see Lévi-Strauss's position with regard to composition poetry in, for example, his classification of composers on the basis of partially defined structural linguistic communication models for music and the cognitive and emotional functions of music. This is at the level of "codes" and "sharing" with the added attribute of "myth". The composers are separated into three groups with varying levels of crossover and combination options. The composers are always specified in pairs comprising one classical and one modern composer for reasons of simplification and standardisation. Lévi-Strauss names J. S. Bach and Igor Stravinsky as typical composers concerned with code (they use their messages to illustrate and comment on the rules of musical discourse). Ludwig van Beethoven and Maurice Ravel are placed in the group of composers concerned with a message (the predominant feature of their work is telling a story). The third category, comprising composers of myth, includes Richard Wagner and Claude Debussy (their messages are based on elements that are naturally present in their narrative). Using the same sequence of categorisation, Lévi-Strauss also classifies composers from the Second Viennese School, specifically Anton Webern, Arnold Schöenberg, and Alban Berg. ${ }^{176}$

\section{Time - Music - Immortality}

One frequently cited sentence from the Overture chapter of The Raw and the Cooked is Lévi-Strauss's characterisation of myth and music with regard to the temporality of human experience: "Both, indeed, are instruments for the obliteration of time." 177 The idea that time is destroyed (suppressed) by myth and music, as presented in this isolated form, is certainly inspirational, but, given its nature, also problematic. It offers the possibility of understanding and applying it purely through a purely structuralist prism, psychologically, philosophically (ontologically), or in a myriad of other ways, which may naturally lead to deformations and shifts in meaning. In relation to this fact, Lévi-Strauss argues that a differentiation must be made between the diachronic time when listening to music, and physiological time. In this particular case, he does not fail to take into account the otherwise overlooked field of psychology. In his view, music, like myth, requires a natural diachronic dimension in order to exist, it takes place in time, and, simultaneously, it transforms time into its own enclosed synchronic form. Music and myth are both able to overcome the passage of historic time as well as the static nature of their own structure. Lévi-Strauss also writes about the two continua of music and myth. The external continuum is based on the course of historical circumstances, which provide the material for creating myths; in the case of music, in musicological terms, one can speak of the dispositional universe

175 For more information, refer to Claude Lévi-Strauss, The Raw and the Cooked, 23-26.

176 Ibid., 29-30.

177 Claude Lévi-Strauss, The Raw and the Cooked, 16. 
of music in the form of sets of tones as the material used for creating a musical work. The internal continuum is dependent on the internal time of the listener. Lévi-Strauss refers to the issues associated with physiological time, the periodicity of brainwaves, organic rhythms, and the memory capacity of the human brain. Music, in his opinion, contains psychological, physiological and visceral time. He generally completes his interpretation through applying the basic bipolar oppositions of nature and culture: music operates as two grids - the physiological and the cultural. ${ }^{178}$ Using this basis, Lévi-Strauss's concept of a musical work is internally organised in a structurally synchronous manner (refer to the section that correlates myth to a musical score), and this aspect leads to the suppression of passing time. When listening to music or to myth, their synchronous dimension loses its temporal aspect. Listening to music even brings one to the threshold of the metaphysical: "[...] when we are listening to it, we enter into a kind of immortality." 179 Within the context of this overall theme, both the diachronic as well as synchronic crosssections obviously reflect the inspirational aspects of structural linguistics: the "langue" is found behind the "parole", the paradigmatic is disclosed on the basis of the syntactic. Based on the outline of the theoretical environment of the cited sentence, a quote can be considered from a later interview with Lévi-Strauss that took place in 2001, in which he puts the investigated issues associated with myth and music into concrete terms; specifically, diachronic cultural messages must be "read" synchronically. One could argue that the text included below introduces a much more succinct meaning than that which has been presented by a number of other authors in the past:

CLS [Claude Lévi-Strauss]: But in speaking of a time-cancelling machine I wasn't trying to say anything profound or important. I only wanted to say that what is important for understanding a myth is not following the progress of the story but recognizing that it is made up of superposed slices like the parts of a score and therefore has to be grasped outside the linear time that we are accustomed to, just as when we have really listened to a piece of music our memory reassembles the phrases we have heard into a whole. I don't think there is any philosophical message here! ${ }^{180}$

\section{Bolero}

As far as his theses regarding the homology of myth and music are concerned, Lévi-Strauss did not remain at purely the theoretical level, as is evidenced by the well-known analysis of Maurice Ravel's Bolero (1928) he presents in the Finale chapter of The Naked Man. ${ }^{181}$ Even though one might question the representative nature of the specific composition

178 Ibid., 16-17.

179 Ibid., 16.

180 Marcello Massenzio, "An Interview with Claude Lévi-Strauss," Current Anthropology 42, No. 3 (2001): 421.

181 For more information, refer to Claude Lévi-Strauss, The Naked Man, 659-667. 
he selected, this analytical experiment provides convincing and inventive proof of the structure of music, which can even be appreciated by a musicologist with his entire set of analytical tools. In the presentation of Bolero, there is of course the intent to confirm the deeper methodological basis of the musical analysis of myth - the structural presence of binary oppositions and how they are overcome, a confirmation of the identical approach in myth and in musical works. Whilst, according to Ravel, one might traditionally interpret Bolero as an "orchestral crescendo" or as a textbook example of orchestral instrumentation, Lévi-Strauss attempts to reveal certain aspects of the composition about which the composer is de facto not aware and which are associated with myth and the unconscious structure of the universality of human thought. In addition, it is possible to see the presence of the equally important aspect of transformation - in this case, the musical material, its components, and its facets. Pandora Hopkins draws attention to Lévi-Strauss's described intent when she states: "His aim is to find unconscious structuring in the work-patterns that have manifested themselves despite the avowed intention of the composer [...]." 182 The tectonic and structural principles of Bolero are once again the same as those of certain myths that are based on their spiralling growth, dynamic progress, and the gradual introduction of musical texture resulting from the presence of contradictions. Lévi-Strauss reveals these moments in the presence of contrasts within the musical thoughts of the composition: subject/answer and counter-subject/counter-answer in periodic succession. The accompanying ostinato motif, which is the opposite of the main undulating melody, reflects the internal presence of the intertwined ternary and binary rhythms and the $3 / 4$ metre, and, no less importantly, the overall modulation and tonal contrast of the subject (expressed for the first time in $\mathrm{C}$ major on the flute) and the counter-subject in the composition (expressed for the first time on the clarinet; although the counter-subject drifts towards F minor, it never reaches that point). These oppositions form the backbone of the composition. According to Lévi-Strauss, Ravel, at the beginning of the piece, shifts his attention to the orchestration and timbral aspects, which are not however the determinant factors. After exhausting the timbral complexity of the instruments that are played and their various combinations in solos, duos, and groups, there is a necessary escalation and the aforementioned internal opposites are transformed in a manner that is entirely unexpected: the sudden modulation of the $\mathrm{C}$ major key into E major shortly before the finale and the return to the main tonality. According to LéviStrauss, the E major key, in addition to taking on the harmonic function of the major mediant in the $\mathrm{C}$ major tonality, is also in the structurally mediant position, which plays a key role in bridging all of the existing opposites. E major is the parallel key of $\mathrm{C}$ minor and is distantly related to the F minor key, towards which the counter call drifts (the tonality in $\mathrm{C}$ minor is a chromatic shift of the enharmonic third that is interchangeable with the D flat major chord, which belongs to the F minor tonality, and the F minor chord is the minor subdominant of $\mathrm{C}$ major). The modulation is therefore the mediation that

182 Pandora Hopkins, "The Homology of Music and Myth: Views of Lévi-Strauss on Musical Structure," Etnomusicology 21, No. 2 (1977): 254. 
determines the elements of the composition's structure. Lévi-Strauss loosely compared Bolero to a fugue "laid out flat" due to the presence of linearly developing motifs, themes, and elements concealing incompatibility, the individual voices succeeding each other as if they were pursuing one other and becoming interwoven. Even though the described analysis confirms the correctness of the principles contained in Lévi-Strauss's overall theory, it cannot be absolutely applied to all musical works and can by no means be called unproblematic. ${ }^{183}$

\section{Musicological Applications and Critical Reflections}

The presence of mythological links in musical works, as defined in Lévi-Strauss's concept, has been reflected in the inspiration for a number of musicological applications and a further elaboration of this concept. I should like to draw attention to some of them with the aim of expanding the fairly narrow theoretical focus of the analyses presented in Lévi-Strauss's texts.

Carl Dahlhaus addressed the temporal aspect of myth and music and the concept of binary oppositions in his analysis of Wagner's music. In his case, the primary methodological interest in analysis takes into account the synchronic and diachronic aspect of myth and how it is reflected in the horizontal and vertical dimensions of music in an orchestral score. Amongst other things, Dahlhaus works with the duality of historical time ("in time") and time as an aesthetic phenomenon ("out of time"). ${ }^{184}$

One can also see the application of the methodological ideas contained in Lévi-Strauss's works in Eero Tarasti's classic monograph Myth and Music (1978). Tarasti revises the initial theory and expands it further within the context of musical semiotics with the use of communication theory, primarily through the narrative model of myth and music. When defining the mythical style in music, Tarasti uses the relationships between myth and music as outlined by Lévi-Strauss but also critically notes: "However, Lévi-Strauss

183 Pandora Hopkins, for example, emphasises the listening strategy for a work that may not perceptually fit in with Lévi-Strauss's idea. The novelty of Bolero may be seen in the new relationships between traditionally used elements and the important aspect of mass tone colour. Ibid., 253-257. Nikolaus Bacht contemplates the origin of constitutive oppositions and whether they are truly polar (as far as the structuring of music as such is concerned) or if, in Bolero they are not merely derived from the initial motif/subject. The modulation in the finale of the composition does not therefore resolve contradictions, but is the logical culmination of the composition. Nikolaus Bacht, "Enlightenment from Afar. The Structural Analogy of Myth and Music According to Claude Lévi-Strauss," Acta Musicologica 73, No. 1 (2001): 12-15. Eero Tarasti also addresses the analysis of Bolero and describes its structuring principle as mythical with more frequent occurrences, and demonstrates this using the compositions of Dmitri Shostakovich and Jan Sibelius. Eero Tarasti, Myth and Music. A Semiotic Approach to the Aesthetics of Myth in Music, especially that of Wagner, Sibelius and Stravinsky (Helsinki: Suomen Musiikkitieteellinen Seura, 1978), 32-38.

184 Carl Dahlhaus, "Analyse des Mythos: Claude Lévi-Strauss und Der Ring des Nibelungen," in Klassische und romantische Musikästhetik (Laaber: Laaber-Verlag, 1988), 458-467. 
overlooks one possible relation between myth and music: he does not discuss a case in which music could acquire meaning or content from mythology, just as mythology could in part acquire sound from music, as it does in a ritual, for example, where myth may be performed with a song melody." 185

Victoria Adamenko, who is influenced by, amongst other things, the Moscow-Tartu semiotic school, makes substantial use of Lévi-Strauss's theses in her analysis and interpretation of neo-mythologism in $20^{\text {th }}$ century compositions. Using them as a foundation and applying an interdisciplinary approach, she reveals the use of the structural, expressive, and textual elements of myth (the constitutive function of binary oppositions, symbolic numbers and cosmology) in the compositional work of selected composers. ${ }^{186}$

Nikolaus Bacht presents yet another application of Lévi-Strauss's theory. He draws attention to the time delay in the adaptation of the structuralist method within the field of music analysis and criticises certain non-beneficial experiments as being carried out in the spirit of vulgar Lévi-Straussianism. He emphasises the importance of the structuralist analyses of Nicolas Ruwet, which preceded the texts of Jean Jacques Nattiez mentioned below. He also mentions the critiques of post-structuralists and post-modernists (Gilles Deleuze, Félix Guattari, Jean-François Lyotard and Jacques Derrida) as they are directed at Lévi-Strauss and structuralism itself. ${ }^{187}$

An interesting application may be seen in Luciano Berio's Sinfonia, for 8 amplified voices \& orchestra (1968-1969), which, amongst other things, uses some of Lévi-Strauss's text from The Raw and the Cooked in the external sentences of his five-part structure. Here one finds not only textual references to myth, but also structural references in the way oppositions are handled in the phonetic area of the texts and musical material that are used. From the structural perspective, the composition contains a musical form corresponding to the type of myth that has two entirely different motifs but ultimately ends by merging them through placing repeated emphasis on the details of these motifs. Lévi-Strauss stated that this myth form had not yet found its musical counterpart in compositions. The musicalisation of this myth was subsequently found, as is known, in the Toccata for piano op. 62 (1964) composed by Lévi-Strauss's friend René Leibowitz. In his analysis, David Osmond-Smith demonstrates that the described structure is also present in Berio's composition. ${ }^{188}$

Lévi-Strauss's daring concept of the homology of myth and European art music did not remain without critical commentaries and rejections, however, both from anthropology and related fields as well as from the field of musicology. The previously cited Pandora Hopkins comprehensively addressed this point from the musicological perspective. In her

185 Eero Tarasti, Ibid., 30.

186 Victoria Adamenko, Neo-Mythologism in Music. From Scriabin and Schoenberg to Schnittke and Crumb (New York: Hillsdale, 2007).

187 Nikolaus Bacht, Ibid., 19-20.

188 For more information, refer to David Osmond-Smith, "From Myth to Music: Lévi-Strauss's 'Mythologiques' and Berio's 'Sinfonia',' The Musical Quarterly 67, No. 2 (1981): 230-260. 
view, from the perspective of more general methodological and philosophical issues, attention should be drawn to the presence of too many generalisations in the theory, and the vagueness in the binary structuring in relation to any sort of empirical material. Another area that is questioned is the premise of the universality of human thought processes and their verifiable transferability between culturally determined areas of myth and art, not to mention the radical differences in the time and place of separate social groups in the case of the myths of native American tribes and the elite culture of Europe with its own traditions. One should also consider the frequently repeated criticism of Eurocentrism with regard to the models of myth analysis and also as concerns the narrowing down of the musical universe into categories of musical works with all of their implications, the inadequate coverage of the musical phenomenon of improvisation, the communication channels of music separated according to creator and interpreter, and the levels of sharing. Hopkins also states, however, that many negative critiques have been the result of misunderstandings, such as in the case of Lévi-Strauss's well-known theses of the untranslatability of myth and music, as in the case of myth it is not possible to obtain the original (superior, correct) version. Lévi-Strauss apparently meant the original version of a myth in its original language; he was not referring to its structure. In his view, myths always exist in relation to other myths in all of their variations. In this regard, methodological help with the analysis of music is appropriate, as it points out the principle of variation as one of the basic principles for shaping music. ${ }^{189}$

Jean Jacques Nattiez subjects Lévi-Strauss's work to criticism from the position of semiotics and structural analysis as such, because, according to him, the investigated topic will always be problematic if it continues to be viewed through the prisms of other disciplines. Nattiez points out, for example, the issues associated with the synchronic and diachronic dimension of myth and music, the fact that the theory itself may be falsified and the reduction of the analysis of myths using music to an aesthetic level on the basis of judgement. ${ }^{190}$

Nikolaus Bacht writes about the ever-present interconnectivity between myth and history, particularly in the European context. In his opinion, this makes it impossible to apply Lévi-Strauss's process directly and to connect European and non-European cultures. "His concept of an universal logic, or metalanguage, abstracted from supposedly ahistorical myth, is not applicable to West European music, which stands firmly in history." 191

189 Pandora Hopkins, Ibid., 248-251.

Jean Jacques Nattiez, Ibid., 57-71. Refer also to Jean Jacques Nattiez, Lévi-Strauss musicien: Essai sur la tentation homologique (Arles: Actes sud, 2008).

191 Nikolaus Bacht, Ibid., 18. 


\title{
Conclusion
}

In spite of many questionable moments, the musical component of Claude Lévi-Strauss's work is an integral and logical part of the structuralist investigation of myth. In this study I have focused on some of the problematic spheres in relation to music, which were interpreted in several different areas. The structural homology of myth and music with an ontological and epistemological status pertains to Lévi-Strauss's analysis of the relationships between myth and music and how they are linked to language, which becomes apparent with the use of linguistic terminology and the creation of a coherent system. Any generalisation of the relationships between myth and music prevents them from being understood as a closed system and being externally non-transferable. Myth analysis carried out by using the method for reading a musical score and the thesis regarding myth as a machine that suppresses time may be described as methodological metaphors. In spite of the link to the homological correlation between myth and music, an emphasis is placed on a practical analytical process. Lévi-Strauss's statements regarding the formal links between music and myth match the idea that a connection exists between the unconscious structures of the human mind in various cultural societies outside the framework of mere ethnography and anthropology. In the case of musicology, the links associated with the stylistic and structural changes in musical expression that have taken place from the Renaissance to the $19^{\text {th }}$ century and the way in which music has assumed mythical forms, as well as the commentaries on serial music, remain inspirational aspects. LéviStrauss's observations concerning the typology of composers and compositional poetry are of a supplemental nature. Conversely, the analysis of Ravel's Bolero provides an innovative view of musical structure and musical analysis methodology. By identifying these problematic aspects associated with the role music plays in myth analysis, attention has been drawn to their possible semantic intent, within the framework of which they should be construed and critiqued. In conclusion, I consider the musical legacy in the works of Lévi-Strauss to be an expression of the scientific and philosophical view of a European individual who penetrated the depths of mythical thought whilst remaining firmly rooted in his own cultural traditions.

\section{A Musical Analysis of Mythical Thought in the Work of Claude Lévi-Strauss}

\begin{abstract}
This study addresses the music-related aspects of the works of Claude Lévi-Strauss within the context of musicology and with a specific focus placed on his Mythologiques tetralogy. The aim is to define thematic categories for the individual theses within which they are further contextually understood. Selected references to music from Lévi-Strauss's work were analysed, compared, and interpreted, taking into consideration the theories of structural linguistics and anthropology. The topics chosen for the investigation include the
\end{abstract}


system of relationships between language, mythology, and music, the analysis of myths using musical scores, the thesis that both music and myth are instruments that suppress time, the mythical nature of musical forms, and an analysis of Maurice Ravel's Bolero. The study takes into account current musicological applications that use the structural analysis of myths, and also critical reflections regarding Lévi-Strauss's theories. The individual categories were defined as structural homologies of myth and music, methodological tools of a metaphorical type to analyse myths using music, and the area commenting on the principles governing the styles and forms in the development of European art music and composed poetry.

\title{
Hudební analýza mytologického myšlení v díle Clauda Lévi-Strausse
}

\begin{abstract}
Abstrakt
Studie se zabývá hudební linií díla Clauda Lévi-Strausse v kontextu muzikologie se zaměřním na cyklus Mythologiques. Cílem je vytvořit tematické okruhy, do kterých jednotlivé teze spadají, a ve kterých jsou dále kontextově chápány. Vybrané odkazy v jeho textech k hudbě byly analyzovány, komparovány a interpretovány se zohledněním teorií strukturální lingvistiky a antropologie. Jako předmět zkoumání jsme zvolili systém vztahů mezi jazykem, mýtem a hudbou, analýzu mýtu pomocí hudební partitury, teze o hudbě a mýtu jako nástrojů k ničení času, mytologický charakter hudebních forem, analýzu Bolera Maurice Ravela. Zohledněny jsou aktuální muzikologické aplikace strukturální analýzy mýtu a kritická reflexe Lévi-Straussovy teorie. Jednotlivé okruhy byly vymezeny jako strukturní homologie mýtu a hudby, metodologické nástroje metaforického typu k analýze mýtu pomocí hudby, oblast komentářů ke stylovým a formovým zákonitostem vývoje evropské umělecké hudby a skladatelských poetik.
\end{abstract}

\section{Keywords}

Claude Lévi-Strauss; structuralism; Mythologiques; ethnomusicology; myth; mythology; music; musical analysis; Bolero.

\section{Klíčová slova}

Claude Lévi-Strauss; strukturalizmus, Mythologiques; etnomuzikologie; mýtus; mytologie; hudba; hudební analýza; Bolero. 